\title{
Working Capital Trends and Liquidity Analysis of Fmcg Sector in India
}

\author{
Shweta Mehrotra \\ Research Scholar, Faculty Of Commerce, Banaras Hindu University, India.
}

\begin{abstract}
Management of Working Capital is one of the most important functions of corporate management. Every organization whether public or private, profit oriented or not, irrespective of its size and nature of business, needs adequate amount of working capital. The efficient working capital management is most crucial factor in maintaining survival, liquidity, solvency and profitability of the any business organization. A company needs sufficient finance to carry out purchase of raw materials, payment of day-to-day operational expenses and funds to meet these expenses are collectively known as working capital. Keeping in view the significance of working capital management as a gray area of corporate finance function, an attempt has been made to examine the working capital trends and practices particularity in FMCGs sector in India by selecting five FMCGs companies (named as Hindustan Unilever Limited, Nestle India Limited, Britannia Industries, Procter $\&$ Gamble and ITC). The FMCG sector in India is at present, the fourth largest sector with a total market size in excess of USD 13 billion as of 2012. This sector is expected to grow to a USD 33 billion industry by 2015. This industry primarily includes the production, distribution and marketing of consumer packaged goods, that is those categories of products which are consumed at regular intervals. The study is based on secondary data i.e. Annual Reports of the selected companies. The period of study is five years and traditional method of data analysis and ratio analysis as tools of financial statement analysis for examine the degree of efficiency of working capital management has been adopted.
\end{abstract}

Keywords: Current Assets, Financial Ratios, FMCG sector, Liquidity analysis, Working capital management.

\section{Introduction}

The concept of WC is very vital because the term used for the capital needed for the day-to-day operation. Adam Smith (1776) explained, "The goods of the merchant yield him no revenue or profit, till he sells them for money, and the money Yields him as little till it is again exchanged for goods. His capital is continuously going from him $8 \mathrm{n}$ one shape, and returning to him in another, and it is only by means of such circulation, or successive exchanges, that it can yield him profit; such capital therefore, may very properly be called circulating capital." What we called working Capital Smith called circulating capital. This capital is needed for regular business operation such as purchase of raw materials, payment of direct and indirect expenses carry on production, investment in stock and store, credit granted to customers keeping balance, etc. Decisions relating to working capital and short -term financing are referred to as WCM. It is best described as the administration of all aspects of current assets and current liabilities. The objectives of WCM are to ensure that the firm is able to continue its operations and that it has sufficient cash flow to satisfy both maturing short- term debt and upcoming operational expenses. WCM therefore, consists of: a) considering the trade- off between costs and benefits derived from alternative levels of investment in WC and: b) managing of both control and decisions regarding stock, debtors and cash. According to Harris (2005) Working capital management is a simple and straightforward concept of ensuring the ability of the firm to fund the difference between the short term assets and short term liabilities. Nevertheless, complete mean and approach preferred to cover all its company's activities related to vendors, customer and product. (Hall, 2002). Now a day working capital management has considered as the main central issues in the firms and financial managers are trying to identify the basic drivers and level of working capital management (Lamberson, 1995). The working capital meets the short-term financial requirements of a business enterprise. It is a trading capital, not retained in the business in a particular form for longer than a year. The money invested in it changes form and substance during the normal course of business operations. The need for maintaining an adequate working capital can hardly be questioned. Just as circulation of blood is very necessary in the human body to maintain life, the flow of funds is very necessary to maintain business. If it becomes weak, the business can hardly prosper and survive. Working capital starvation is generally credited as a major cause if not the major cause of small business failure in many developed and developing countries (Rafuse, 1996). The success of a firm depends ultimately, on its ability to generate cash receipts in excess of disbursements. The cash flow problems of many small businesses are exacerbated by poor financial management and in particular the lack of planning cash requirements (Jarvis et al, 1996). The study objectives are to examine the working capital management of the sample firms. The amounts invested in working capital are often high in proportion to the total assets employed and so it is vital that these 
amounts are used in an efficient and effective way. However, there is evidence that small businesses are not very good at managing their working capital.

\section{Objectives}

The study aims at analyzing the working capital management of FMCG (fast moving consumer goods)

Sector in India. The main objectives are:

- To analyze the working capital trends in FMCG sector;

- To discover the relative importance of various current assets components;

- To draw conclusion on the effectiveness of working capital management;

- To study:

How the companies handle debtors

How they handle inventories

How they manage other current assets

\section{Working Capital Trends and Liquidity analysis}

In the present study an attempt has been made to analyze, assess and evaluate the working capital management (WCM) through ratio analysis and WC trends and liquidity position of some selected FMCG companies in India for the period of five years. These companies rare: Hindustan Unilever Limited (HUL), ITC Ltd, P\&G India, Britannia Industries and Nestle India. The study uses secondary data that have been extracted from the annual reports of the selected FMCG companies. The methodology followed in this study includes techniques of financial analysis, such as ratio analysis which deal with every aspect of WC (working capital), computation of ratios and their comparison with the fixed standards._It has been shown as company wise working capital analysis.

WC can solve a large portion of the firm's total assets, more than half of a typical firm's total investment is in current assets. In any industrial undertaking the major components of working capital are inventories, sundry debtors, cash and bank balances and loan and advances. Since the level of WC determines the liquidity position of a firm, the WC trend and liquidity analysis of the units under study have been discussed below.

\section{Hindustan Unilever limited (HUL)}

Hindustan Unilever limited (HUL) is India's largest FMCG Company with the heritage of over 75 years in India. As per Nielsen market research data, two out of three Indians use HUL products. It is owned by the British-Dutch company Unilever which controls 52\% majority stake in HUL. Its products include foods, beverages, cleaning agents and personal care products. HUL was formed in 1933 as Lever Brothers India Limited and came into being in 1956 as Hindustan Lever Limited through a merger of Lever Brothers, Hindustan Vanaspati Mfg. Co. Ltd. and United Traders Ltd. Lever Brothers started its actual operations in India in the summer of 1888, when crates full of Sunlight soap bars, embossed with the words "Made in England by Lever Brothers" were shipped to the Kolkata harbor and it began an era of marketing branded Fast Moving Consumer Goods (FMCG)

HUL works to create better future every day and helps people feel good, look good and get more out of life with brands and services. With over 35 brands spanning 20 distinct categories such as soap, detergents, shampoos, skin care, toothpastes, deodorants, cosmetics, tea, coffee, water purifiers, etc. the company is a part of the everyday life of millions of consumers across India. Its portfolio includes leading household brands such as Lux, Lifebuoy, SurfExcel, Rin, Wheel, Fair \& Lovely, Pond's, Vaseline, Lakme, Dove, Clinic Plus, Sunsilk, Pepsodent, CloseUp, Axe, Brook Bond, Bru, Knorr, Kissan, Kwality Wall's and Pureit. The company has over 16000 employees and has an annual turnover of around Rs.19400 corers (financial year 2010-2011). Over the last two years, HUL have added one million new stores, doubling its coverage and taking the HUL products and services to some of the remotest corners.

In India, HUL is known for its tight management of working capital and the company has been operating with a negative working capital since 2000. But the management realized that as competition intensifies, there is still scope for improving operational efficiency and cutting working capital needs. Unilever companies in India integrated all aspects of finance, accounting and logistics into one all-embracing commercial function. "Commercial" focused on cutting working capital requirements through innovative supply chain management and use of Information Technology to improve the efficiency of transactions. 
Working Capital Trends And Liquidity Analysis Of Fmcg Sector In India

Table1A: Working Capital Trends and Liquidity Analysis of HUL from December 2007 to March 2012

(Rs. In crore)

\begin{tabular}{|c|c|l|l|l|c|}
\hline & March 2012 & March 2011 & March 2010 & March 2009 & December 2007 \\
\hline Inventories & 2516.65 & 2811.26 & 2179.93 & 2528.86 & 1953.60 \\
\hline Sundry Debtors & 678.99 & 943.20 & 678.44 & 536.89 & 443.37 \\
\hline $\begin{array}{c}\text { Cash \& Bank } \\
\text { Balance }\end{array}$ & 510.05 & 281.91 & 231.37 & 190.59 & 200.11 \\
\hline $\begin{array}{c}\text { Loan \& } \\
\text { Advances }\end{array}$ & 1314.72 & 1099.72 & 1068.31 & 1196.95 & 1083.28 \\
\hline $\begin{array}{c}\text { Total Current } \\
\text { Assets }\end{array}$ & 6340.40 & 6494.19 & 5818.89 & 6040.05 & 3681.11 \\
\hline $\begin{array}{c}\text { Total Current } \\
\text { Liabilities }\end{array}$ & 7634.36 & 7589.19 & 6935.52 & 5968.06 & 5302.31 \\
\hline $\begin{array}{c}\text { Net Current } \\
\text { Assets }\end{array}$ & -1293.96 & -1095.00 & -1116.63 & 71.99 & -1621.20 \\
\hline
\end{tabular}

Source: Compiled from the Annual Reports of HUL.

Table 1B: Key Financial Ratios of HUL

\begin{tabular}{|c|c|c|c|c|c|}
\hline & $\begin{array}{c}\text { March } \\
2012\end{array}$ & March 2011 & $\begin{array}{c}\text { March } \\
2010\end{array}$ & March 2009 & $\begin{array}{c}\text { December } \\
2007\end{array}$ \\
\hline Operating Profit per share (Rs.) & 15.38 & 12.34 & 12.82 & 13.60 & 9.54 \\
\hline Operating Profit Margin (\%) & 15.03 & 13.53 & 15.74 & 14.46 & 14.95 \\
\hline Gross Profit Margin (\%) & 14.04 & 12.41 & 14.70 & 13.50 & 15.86 \\
\hline Net Profit margin (\%) & 12.07 & 11.56 & 12.29 & 12.69 & 12.58 \\
\hline Current Ratio & 0.83 & 0.86 & 0.84 & 0.92 & 0.68 \\
\hline Quick Ratio & 0.45 & 0.43 & 0.46 & 0.51 & 0.25 \\
\hline Inventory Turnover Ratio & 9.93 & 7.91 & 8.99 & 9.26 & 7.20 \\
\hline Debtors Turnover Ratio & 27.27 & 24.28 & 29.24 & 41.83 & 31.41 \\
\hline Investment Turnover Ratio & 9.93 & 7.91 & 8.99 & 9.26 & 8.20 \\
\hline Fixed Assets Turnover Ratio & 6.26 & 5.63 & 5.35 & 7.81 & 9.80 \\
\hline Total Assets Turnover Ratio & 6.37 & 8.31 & 7.66 & 9.22 & 10.53 \\
\hline Average Finished Goods held & 29.08 & 35.15 & 32.05 & 34.18 & 29.81 \\
\hline Number of days in working & -21.06 & -20.02 & -22.62 & 1.5 & -42.05 \\
\hline
\end{tabular}

It is evident from the above mentioned Table that among current assets inventories has the largest share and it dominants the gross working capital during study period. Inventories and Loan and Advances represent almost more than 50 per cent of gross working capital except during March 2009-2010. The current ratio or working capital ratio is perhaps the most universally used of all the ratios. Ti measures the ability of the firm to pay off its short- term maturity obligations. It demonstrates how quickly a company can meet its short- term obligations. It can be observed from the table that the current ratio of HUL varies between 0.68 and 0.92 during last five years. It is evident that on an average, per every one rupee of current assets, the company has been managing 0.206 rupee of current assets as a caution to meet its current liabilities. Quick ratio ranges between 0.25 and 0.51 during study period. It is a more severe test of liquidity than current ratio. On an average the company has maintained 0.205 rupee of current assets except inventories against the standard quick ratio i.e.1:1. Inventory turnover ratio is highest (9.93 times) in March 2012 and lowest (7.20 times) in December while Debtor turnover ratio was highest (41.83 times) in March 2009 and lowest (24.28 times) in March 2011. Debtors management appears to be quite satisfactory as more the number of times debtors turnover, better the liquidity position of the company.

Number of days in working capital is used to describe how many days a company will take to convert its working capital into revenue and fewer the number of days it is better. A short working capital cycle means a business has good cash flow. However, HUL has negative working capital during study period except in 2009. A negative working capital cycle means what a company purchases and sells turns into cash quicker than it has to pay to its creditors and has more capital available to fund growth. For a business to grow it needs access to cash and being able to free up cash from working capital cycle is cheaper than other sources of finance such as loans. 


\section{ITC Limited}

ITC Limited is an Indian public conglomerate company (25.4\% owned by British corporation, British American Tobacco) headquartered in Kolkata, West Bengal, India Its diversified business includes four segments: Fast Moving Consumer Goods (FMCG), Hotels, Paperboards, Paper \& Packaging and Agri Business. ITC's annual turnover stood at \$7 billion and market_capitalization of over \$34 billion. The company has its registered office in Kolkata. It started off as the Imperial Tobacco Company, and shares ancestry with Imperial Tobacco of the United Kingdom, but it is now fully independent, and was rechristened to India Tobacco Company in 1970 and then to I.T.C. Limited in 1974. The company is currently headed by Yogesh Chander Deveshwar. It employs over 29,000 people at more than 60 locations across India and is listed on Forbes 2000. ITC Limited completed 100 years on 24 August 2010.

ITC has a diversified presence in FMCG (Fast Moving Consumer Goods), Hotels, Paperboards \& Specialty Papers, Packaging, Agri-Business and Information Technology. While ITC is an outstanding market leader in its traditional businesses of Hotels, Paperboards, Packaging, Agri-Exports and Cigarettes, it is rapidly gaining market share even in its nascent businesses of Packaged Foods \& Confectionery, Branded Apparel, Personal Care and Stationery.

Table 2A: Working Capital Trends and Liquidity Analysis of ITC Ltd. from 2008 to 2012

\begin{tabular}{|l|c|c|c|c|c|}
\hline & March 2012 & March 2011 & March 2010 & March 2009 & March 2008 \\
\hline \multicolumn{1}{|c|}{ Inventories } & 5637.83 & 5267.53 & 4549.07 & 4599.72 & 4050.52 \\
\hline Sundry Debtors & 986.02 & 907.62 & 858.80 & 668.67 & 736.93 \\
\hline $\begin{array}{l}\text { Cash \& Bank } \\
\text { Balance }\end{array}$ & 140.50 & 988.77 & 120.16 & 68.73 & 153.34 \\
\hline $\begin{array}{l}\text { Loan \& } \\
\text { Advances }\end{array}$ & 1952.54 & 2173.89 & 1929.16 & 2150.21 & 1949.29 \\
\hline $\begin{array}{l}\text { Total Current } \\
\text { Assets }\end{array}$ & 11395.32 & 10592.28 & 8463.31 & 8450.99 & 7306.99 \\
\hline $\begin{array}{l}\text { Total Current } \\
\text { Liabilities }\end{array}$ & 10519.67 & 9772.94 & 9169.48 & 5862.08 & 5265.09 \\
\hline $\begin{array}{l}\text { Net Current } \\
\text { Assets }\end{array}$ & 875.65 & 819.34 & -706.17 & 2588.91 & 2041.90 \\
\hline
\end{tabular}

Source: Compiled from the Annual Reports of ITC Ltd.

Table 2B: Key Financial Ratios of ITC Ltd.

\begin{tabular}{|l|l|l|l|l|l|}
\hline & $\begin{array}{l}\text { March } \\
2012\end{array}$ & $\begin{array}{l}\text { March } \\
2011\end{array}$ & $\begin{array}{l}\text { March } \\
2010\end{array}$ & $\begin{array}{l}\text { March } \\
2009\end{array}$ & $\begin{array}{l}\text { March } \\
2008\end{array}$ \\
\hline Current Ratio & 1.08 & 1.08 & 0.92 & 1.42 & 1.36 \\
\hline Quick Ratio & 0.51 & 0.50 & 0.39 & 0.61 & 0.56 \\
\hline Inventory Turnover Ratio & 6.53 & 6.05 & 6.04 & 5.26 & 5.51 \\
\hline Debtors Turnover Ratio & 26.50 & 23.91 & 24.31 & 21.32 & 20.43 \\
\hline Investment Turnover Ratio & 6.53 & 6.05 & 6.04 & 5.26 & 5.51 \\
\hline Total Assets Turnover Ratio & 1.34 & 1.34 & 1.33 & 1.09 & 1.61 \\
\hline $\begin{array}{l}\text { No. of days in working } \\
\text { capital }\end{array}$ & 12.56 & 13.97 & -13.69 & 62.19 & 52.39 \\
\hline Average finished goods held & 40.51 & 40.67 & 36.33 & 64.35 & 43.88 \\
\hline
\end{tabular}

It can be observed from the above-mentioned Table that ITC limited is dealing with positive working capital during study period except in March 2010. During March 2010 current liabilities shown drastic increment of 56 per cent but current assets remained almost constant. Among total current assets inventory has the largest share and it comprises more than 50 per cent of gross working capital. Loans and advances has second largest share in gross working capital in last five years. The current ratio of the company ranges between 0.92:1 and 1.42:1. It means on an average per every one rupee of current liabilities, the company has been maintaining 1.17 rupees of current assets as a caution to meet its short- term obligations which is good. Quick ratio varies between 0.39:1 and 0.61:1 during the period. It has been noticed that there was continuous increment in debtors' turnover ratio and inventory turnover ratio. Moreover the table disclosed a mean value of debtors' turnover ratio at 23.29 times which indicates effective debtor management. As for as Number of days in working capital is concerned, number of days in working capital has been decreased during the study period and even it turned into negative in 2010. Fewer the number of days better the position and it means the company has better cash flow. 


\section{Proctor \& Gamble (P\&G) India}

$\mathrm{P} \& \mathrm{G}$ is one of the largest and amongst the fastest growing consumer goods companies in India. Established in 1964, P\&G India now serves over 650 million consumers across India. Its presence pan across the Beauty and Grooming segment, the Household Care segment as well as the Health and Well Being segment with trusted brands that are household name across India. These include Vicks, Ariel, Tide, Whisper, Olay, Gillette, Ambipur, Pampers, Pantene, Oral-B, Head \& Shoulders, Wella and Duracell.

Table3A: Working Capital Trends and Liquidity Analysis of P\&G India from 2008 to 2012

(Rs. In Crore)

\begin{tabular}{|l|l|l|l|l|l|}
\hline & June 2012 & June 2011 & June 2010 & June 2009 & June 2008 \\
\hline Inventories & 92.27 & 65.33 & 54.41 & 53.98 & 46.52 \\
\hline $\begin{array}{l}\text { Sundry } \\
\text { Debtors }\end{array}$ & 48.15 & 31.02 & 28.68 & 22.51 & 13.34 \\
\hline $\begin{array}{l}\text { Cash \& Bank } \\
\text { Balance }\end{array}$ & 182.37 & 3.76 & 8.76 & 4.52 & 6.67 \\
\hline $\begin{array}{l}\text { Loan \& } \\
\text { Advances }\end{array}$ & 548.45 & 461.28 & 322.40 & 336.65 & 208.95 \\
\hline Fixed Deposits & 0.00 & 126.19 & 223.57 & 83.51 & 159.81 \\
\hline $\begin{array}{l}\text { Total Current } \\
\text { Assets }\end{array}$ & 871.24 & 687.58 & 637.82 & 501.17 & 435.29 \\
\hline $\begin{array}{l}\text { Total Current } \\
\text { Liabilities }\end{array}$ & 401.49 & 284.98 & 300.01 & 217.94 & 224.61 \\
\hline $\begin{array}{l}\text { Net Current } \\
\text { Assets }\end{array}$ & 469.75 & 402.60 & 337.81 & 283.23 & 210.68 \\
\hline
\end{tabular}

Source: Compiled from the Annual Reports of P\&G India

Table 3B: Key Financial Ratios of P\&G India

\begin{tabular}{|c|c|c|c|c|c|}
\hline & June 2012 & June 2011 & June 2010 & June 2009 & June 2008 \\
\hline Current Ratio & 2.17 & 2.41 & 2.13 & 2.30 & 1.94 \\
\hline Quick Ratio & 1.94 & 2.16 & 1.92 & 2.02 & 1.70 \\
\hline Inventory Turnover & 14.13 & 20.48 & 21.28 & 17.79 & 16.88 \\
\hline Debtors Turnover & 32.78 & 33.54 & 35.21 & 43.11 & 46.03 \\
\hline Investment Turnover Ratio & 14.13 & 20.48 & 21.28 & 17.79 & 16.88 \\
\hline Fixed Assets Turnover Ratio & 3.75 & 3.20 & 3.71 & 3.48 & 3.17 \\
\hline Total Assets Turnover Ratio & 1.86 & 1.67 & 1.69 & 1.76 & 1.86 \\
\hline Average Finished Goods held & - & 18.42 & 23.59 & 30.05 & 28.42 \\
\hline No. of days in working capital & 130.34 & 144.76 & 134.94 & 131.94 & 117.78 \\
\hline
\end{tabular}

From the above-mentioned table it can be viewed that the company has positive working capital throughout study period. It is observed that Loans and advances have major share in gross working capital followed by fixed deposits except in June 2012 (as fixed deposit was nil in 2012). The volume of net working capital has also increased over the study period. Cash and bank balance has lowest share in total current assets except in June 2012 and the percentage of cash and bank balances have been increased i.e. 47 per cent drastically in 2012 as compared to the last year. The current ratio ranges between 1.94 to 2.41 which reflects that there is over investment in current assets and the portions of current assets are almost double the current liabilities during study period. However, inventory turnover ratio disclosing an average value of 18.11 times which means efficient management of inventory and more frequently the stock are sold. Debtor turnover ratio ranges between 32.78 times and 46.03 times and it has shown a decreasing trend during study period which is a pinch for the company. The number of days in working capital of the company is on higher side and it is a sign a company may be facing some cash trouble.

\section{Nestle India}

Nestlé is the world's leading Nutrition, Health and Wellness Company. Its mission of "Good Food, Good Life" is to provide consumers with the best tasting, most nutritious choices in a wide range of food and beverage categories and eating occasions from morning to night. The Company was founded in 1866 by 
Henri Nestlé in Vevey, Switzerland, where our headquarters are still located today. We employ around 2, 80,000 people and have factories or operations in almost every country in the world.

It is evident from the following table that inventories has the largest share (almost more than 50 per cent) in gross working capital followed by loans and advances. The table is also disclosing that the company is dealing negative working capital as the total current liabilities are more than total current assets. The current ratio of the company is very low i.e.0.60:1 on an average as against the standard ratio i.e. as per Tandon Committee ${ }^{1}$ which indicates that the company is maintaining only 0.60 rupee of current assets as a caution to meet the short-term liabilities. Quick ratio is also very low during study period. Inventory turnover ratio fluctuated between 8.79 times and 12.33 times which means the company has satisfactory inventory management. Debtors' turnover ratio stood at 85.4 times on an average basis during study period which reflects efficient debtor management. Moreover, the company has negative working capital during study period. A negative working capital is a sign of managerial efficiency in a business with low inventory and accounts receivables (which means it operates on an almost strictly cash basis). In other situation, it is a sign a company may be facing bankruptcy or serious financial trouble. However, it is not with Nestle India. In fact, it indicates that it may be collecting money from sale before it pays for goods which mean it has good cash flow.

Table 4A: Working Capital Trends and Liquidity Analysis of Nestle India from December 2007 to December 2012

\begin{tabular}{|c|c|c|c|c|c|}
\hline & $\begin{array}{c}\text { December } \\
2011\end{array}$ & $\begin{array}{c}\text { December } \\
2011\end{array}$ & $\begin{array}{c}\text { December } \\
2009\end{array}$ & $\begin{array}{c}\text { December } \\
2008\end{array}$ & $\begin{array}{c}\text { December } \\
2007\end{array}$ \\
\hline Inventories & 734.04 & 575.95 & 498.74 & 434.911 & 401.22 \\
\hline Sundry Debtors & 115.42 & 63.29 & 64.19 & 45.59 & 53.49 \\
\hline $\begin{array}{c}\text { Cash \& Bank } \\
\text { Balance }\end{array}$ & 25.55 & 19.45 & 26.73 & 12.66 & 15.75 \\
\hline $\begin{array}{c}\text { Loan \& } \\
\text { Advances }\end{array}$ & 256.36 & 200.17 & 184.85 & 162.67 & 186.23 \\
\hline Fixed Deposits & 201.66 & 235.84 & 128.86 & 181.03 & 22.01 \\
\hline $\begin{array}{c}\text { Total Current } \\
\text { Assets }\end{array}$ & 1333.03 & 1094.70 & 903.37 & 836.86 & 678.70 \\
\hline $\begin{array}{c}\text { Total Current } \\
\text { Liabilities }\end{array}$ & 2216.96 & 1751.62 & 1501.18 & 1259.76 & 1027.30 \\
\hline $\begin{array}{c}\text { Net Current } \\
\text { Assets }\end{array}$ & -883.93 & -656.92 & -597.81 & -422.90 & -348.60 \\
\hline
\end{tabular}

Source: Compiled from the Annual Reports of Nestle India

Table 4B: Key Financial Ratios of Nestle India

\begin{tabular}{|l|l|l|l|l|l|}
\hline & $\begin{array}{l}\text { December } \\
2011\end{array}$ & $\begin{array}{l}\text { December } \\
2010\end{array}$ & $\begin{array}{l}\text { December } \\
2009\end{array}$ & $\begin{array}{l}\text { December } \\
2008\end{array}$ & $\begin{array}{l}\text { December } \\
2007\end{array}$ \\
\hline Current Ratio & 0.42 & 0.62 & 0.60 & 0.66 & 0.66 \\
\hline Quick Ratio & 0.24 & 0.27 & 0.24 & 0.29 & 0.23 \\
\hline Inventory Turnover Ratio & 11.60 & 12.33 & 11.61 & 11.39 & 8.79 \\
\hline Debtors Turnover Ratio & 83.83 & 98.22 & 93.68 & 87.37 & 64.09 \\
\hline Investment Turnover Ratio & 11.60 & 12.33 & 11.61 & 11.39 & 10.02 \\
\hline No. of days in working capital & -42.48 & -37.78 & -41.86 & -35.17 & -35.85 \\
\hline Average finished goods held & 22.14 & 22.77 & 22.17 & 26.46 & 28.54 \\
\hline
\end{tabular}

\section{Britannia Industries}

In 1892 to be precise, a biscuit company was started in a nondescript house in Calcutta (now Kolkata) with an initial investment of Rs. 295. The company we all know as Britannia today. The beginnings might have been

\footnotetext{
1. In 1974, a study group under the chairmanship of Mr. P. L. Tandon was constituted for framing guidelines for commercial banks for follow-up \& supervision of bank credit for ensuring proper end-use of funds. The group submitted its report in August 1975, which came to be popularly known as Tandon Committee's Report. Its main recommendations related to norms for inventory and receivables, the approach to lending, style of credit, follow ups \& information system.

Retrivrd from http://rbidocs.rbi.org.in/rdocs/PublicationReport/PDFs/16088.pdf
} 
humble-the dreams were anything but. By 1910, with the advent of electricity, Britannia mechanized its operations, and in 1921, it became the first company east of the Suez Canal to use imported gas ovens. Britannia's business was flourishing. But, more importantly, Britannia was acquiring a reputation for quality and value. As a result, during the tragic World War II, the Government reposed its trust in Britannia by contracting it to supply large quantities of "service biscuits" to the armed forces. As time moved on, the biscuit market continued to grow... and Britannia grew along with it. In 1975, the Britannia Biscuit Company took over the distribution of biscuits from Parry's who till now distributed Britannia biscuits in India. In the subsequent public issue of 1978, Indian shareholding crossed 60\%, firmly establishing the Indianans of the firm. The following year, Britannia Biscuit Company was re-christened Britannia Industries Limited (BIL). Four years later in 1983, it crossed the Rs. 100 crores revenue mark. On the operations front, the company was making equally dynamic strides. In 1992, it celebrated its Platinum Jubilee. In 1997, the company unveiled its new corporate identity "Eat Healthy, Think Better" - and made its first foray into the dairy products market. In 1999, the "Britannia Khao, World Cup Jao" promotion further fortified the affinity consumers had with 'Brand Britannia'. Britannia strode into the 21 st Century as one of India's biggest brands and the pre-eminent food brand of the country. It was equally recognized for its innovative approach to products and marketing: the Lagaan Match was voted India's most successful promotional activity of the year 2001 while the delicious Britannia 50-50 Maska-Chaska became India's most successful product launch. In 2002, Britannia's New Business Division formed a joint venture with Fonterra, the world's second largest Dairy Company, and Britannia New Zealand Foods Pvt. Ltd. was born. In recognition of its vision and accelerating graph, Forbes Global rated Britannia 'One amongst the Top 200 Small Companies of the World', and The Economic Times pegged Britannia India's 2nd Most Trusted Brand.

Table 5A: Working Capital Trends and Liquidity Analysis of Britannia Industries from March 2008 to March 2012

\begin{tabular}{|l|l|l|l|l|l|}
\hline & March 2012 & March 2011 & March 2010 & March 2009 & March 2008 \\
\hline Inventories & 328.28 & 311.20 & 268.34 & 253.63 & 301.53 \\
\hline Sundry Debtors & 52.14 & 57.27 & 39.49 & 49.61 & 46.33 \\
\hline $\begin{array}{l}\text { Cash \& Bank } \\
\text { Balance }\end{array}$ & 30.94 & 27.25 & 18.11 & 40.56 & 43.54 \\
\hline $\begin{array}{l}\text { Loan \& } \\
\text { Advances }\end{array}$ & 391.22 & 351.11 & 211.00 & 209.61 & 185.54 \\
\hline Fixed Deposits & 0.00 & 1.50 & 5.25 & 0.24 & 0.23 \\
\hline $\begin{array}{l}\text { Total Current } \\
\text { Assets }\end{array}$ & 784.59 & 648.33 & 552.19 & 553.65 & 577.49 \\
\hline $\begin{array}{l}\text { Total Current } \\
\text { Liabilities }\end{array}$ & 1124.15 & 625.96 & 510.10 & 437.54 & 370.31 \\
\hline $\begin{array}{l}\text { Net Current } \\
\text { Assets }\end{array}$ & -339.57 & 22.37 & 42.09 & 116.11 & 207.18 \\
\hline
\end{tabular}

Source: Compiled from the Annual Reports of Britannia Industries

Table 5B: Key Financial Ratios of Britannia Industries

\begin{tabular}{|c|c|c|c|c|c|}
\hline & March 2012 & $\begin{array}{c}\text { March } \\
2011\end{array}$ & March 2010 & $\begin{array}{c}\text { March } \\
2009\end{array}$ & March 2008 \\
\hline Current Ratio & 0.70 & 1.04 & 1.08 & 1.27 & 1.22 \\
\hline Quick Ratio & 0.36 & 0.50 & 0.50 & 0.65 & 0.68 \\
\hline Inventory Turnover & 13.15 & 16.68 & 15.08 & 14.54 & 9.98 \\
\hline Debtors Turnover & 90.75 & 87.18 & 76.42 & 64.88 & 69.07 \\
\hline Investment Turnover Ratio & 13.15 & 16.68 & 15.08 & 14.54 & 9.98 \\
\hline Average Finished Goods held & - & 12.58 & 13.81 & 11.59 & 11.08 \\
\hline No. of days in working capital & -24.62 & 1.91 & 4.45 & 14.43 & 28.82 \\
\hline
\end{tabular}

The abovementioned table disclosed that the company was dealing with positive working capital except during March 2011-12 as current liabilities increased drastically by almost 80 per cent as compared to current assets which has rose by only 21 per cent. Moreover, in gross working capital loans and advances has largest share during last two years whereas from March 2010 to March 2008 inventories had the largest share in total current assets. However, fixed deposits have least share in gross working capital and it was nil in March 2012. 
As for as number of days in working capital is concerned, it has shown a declining trend and even turned into negative during march 2010-11. It indicates that the company has good cash flow and negative working capital reflects that the company operates on an almost strictly cash basis with low inventory and accounts receivables.

\section{Conclusion}

More companies go under because of cash flow issues, rather than declining profitability. Hence traditional prudence always suggests that a firm should have sufficient cash to cover its immediate liabilities. However there is a growing breed of FMCG companies that claim otherwise. Unlike most other industries, the turnover of a FMCG company is not limited by its ability to produce, but its ability to sell. They can generate cash so quickly they actually have a negative working capital. This happens because customers pay upfront and so rapidly, the business has no problem raising cash (like amazom.com, McDonald). In these companies products are delivered and sold to the customer before the company even pays for them. Hence they concentrate their resources on marketing and either outsource their manufacturing or make a limited investment (as compared to their turnover) in plant and machinery. Therefore there is a limited room to raise funds by mortgaging the plant and machinery. The developments in SCM, ERP and implementation of JIT have made the firms leaner and hence now it's not possible to raise substantial funds via inventories. Typically a firm pledges its plant, machinery or inventory to raise the bank loan/overdraft required to fund its operation. Realizing these limitations, many companies (esp. Dell and Dabur) starting using their negotiating powers over their customers and suppliers to fund their expansion in operations. A negative working capital is a sign of managerial efficiency in a business with low inventory and accounts receivables (which means it operates on an almost strictly cash basis). In other situation, it is a sign a company may be facing bankruptcy or serious financial trouble.

\section{References}

[1]. M. Anand, Working Capital performance of corporate India: An empirical survey, Management \& Accounting Research, 2001 , Vol. 4(4), pp. 35-65

[2]. H. Bhattacharya, Working Capital Management: Strategies and Techniques, 2001, Prentice Hall, New Delhi

[3]. R.Burns, and J. Walker. A Survey of Working Capital Policy among Small Manufacturing Firms, The Journal of Small Business Finance, 1991 (1), pp. 61-74

[4]. A. Bhunia , A trend analysis of liquidity management efficiency in selected private sector Indian steel industry,2010, International Journal of Research in Commerce and Management, 1: 9-21

[5]. F. Chittenden, Poutziouris and N. Michaelas, Financial Management and Working Capital Practices in UK SMEs, 1998, Manchester, Manchester Business School

[6]. D. Deloof, Does Working Capital Management affect Profitability of Belgian Firms"? Journal of Business Finance and Accounting, 2003, Vol 30 No. 3 \& 4 pp. $573-587$

[7]. R. K. Jain, Working capital management of state enterprises in India.1988, Jaipur, National Publishing House

[8]. P. V. Joshi, Working Capital Management under Inflation, 1995,Anmol Publishers, Delhi

[9]. K. Padachi, Trends in working capital management and its impact on firms performance: an analysis of Mauritian small manufacturing firms, International Review of Business Research Papers, 2006, 2: 45-58

[10]. R.K.S. Rao, Fundamentals of Financial Management. Macmillan Publishers, 1989, 550-644

[11]. M. Reddy, Management of working capital. Vikalpa, 199116 (1): 30-5

[12]. R. Reddy, and P. Kameswari, Working capital management practices in Pharmalindustry: A case study of 'Cipla Limited'. Management Accountant, 2004 August,638-44.

[13]. J.Sagan, towards a theory of working capital management. The Journal of Finance, 1955, 10 (2): 121-9.

[14]. H. H. Shin, and L. Soenen, Efficiency of working capital management and corporate profitability. Financial Practice and Education 1998, 8 (2): 37-45.

[15]. M. R. Siddarth , and G. Das, Working capital turnover in pharmaceutical companies. The Management Accountant, March, 1994, 151-3.

[16]. M. B. Smith, and E. Begemann, Measuring associations between working capital and return on investment. South African Journal of Business Management, 1997, 28 (1): 1-4.

[17]. L.A. Soenen, Cash conversion cycle and corporate profitability. Journal of Cash Management, 1993, 13: 53-58

[18]. Tandon Committee Report .Retrived from http://rbidocs.rbi.org.in/rdocs/PublicationReport/PDFs/16088.pdf

[19]. J.C. Van Horne, Risk-return analysis of a firm working capital. The Engineering Economist 14 (Winter), 1969, 71-89. Managing Global 